The Cracked Glass Ceiling: Equal Work But Unequal Status ${ }^{1}$

Angela R. Dobele*

School of Economics, Finance and Marketing, RMIT University, Australia

Sharyn Rundle-Thiele

Department of Marketing, Griffith Business School, Griffith University, Australia

Foula Kopanidis

School of Economics, Finance and Marketing, RMIT University, Australia

* Email: angela.dobele@rmit.edu.au

\footnotetext{
${ }^{1}$ The authors wish to acknowledge the research assistance provided by Annika Lohneiss.
} 


\section{The Cracked Glass Ceiling: Equal Work But Unequal Status}

The achievement of greater gender equity in Universities continues to warrant attention. Globally, Universities have much work ahead of them if they are to redress the gender imbalance in senior positions and remuneration rates.

This paper contributes to the academic workloads knowledge base, observing individual workloads in two mid-tier business faculties from two Australian universities which had more women employed in junior academic ranks than men. Multiple sources of evidence were used to observe teaching and research workload of academic staff.

Our results show gender equity in terms of workload but inequality in terms of pay and status. Specifically, while workload differences between genders were largely not evident, fewer women were employed in senior ranks. These results suggest, despite policy reforms, inequity continues to be a problem in the Australian higher education sector.

Keywords: case study; gender; higher education; workload; equity 


\section{Introduction}

It would appear, that despite ongoing attention gender inequality still exists globally and as such, gender inequality remains as an important worldwide issue for the higher education sector. The European Technology Assessment Network report, presented over a decade ago, painted a grim picture. At the time, there was no university in Europe where the percentage of female professors corresponded with the percentage of female academic staff or students (Mischau, 2001). Further, even in those countries where the number of female professors was comparatively high, females remained under-represented at more senior levels, including roles such as serving on decision making boards (Mischau, 2001).

Fast forward one decade and the picture remains the same. For example, in America, while the genders are evenly represented at graduate level, the number of women who go on to work in higher education is significantly less than for male graduates (Monroe and Chiu, 2010). Those women that do go on to senior positions can also expect less remuneration when compared to their male counterparts. Since the late 1970 s the average salary for female faculty members remains at just 81 per cent of that earned by their male counterparts. Further, the average salary for women is lower than it is for men within the same academic rank (Gardner, 2007). The differences are not limited to salary but differences also occur in terms of rank, tenure and length of time to promotion for female and male employees in higher education (Lanier, Tanner and Guidry, 2009). Women working in academia are more likely to be employed at institutions with lower statuses, are more likely to be ranked at lower levels and once again females are reported to earn less at each level compared to men in similar positions, with pay levels observed to be three per cent less at lower levels and up to eight per cent less at the highest level (Monroe and Chiu, 2010). Female academics in America at the assistant professor level comprise almost 11 per cent $(10.9 \%)$ of the total population at this level, but this figure drops considerably with only $7.2 \%$ making it to professor in a US research institution. According to Monroe and Chiu (2010), this disparity represents a problem of advancement rather than the absence of qualified female candidates.

Female academics in the UK comprise less than half (42.6\%) of the overall academic staff, however, less than 20 per cent $(18.7 \%)$ are at the head of school or professorial level and male academics are more than twice as likely to be in the top salary bracket (Barrett and Barrett, 2011). Even though the number of female professors has been increasing in Britain over the past years, the gender pay gap continues to be evident (Cooper, 2011).

It is not all doom and underpaid gloom, over the last three decades there have been some improvements in the gender balance of university academic staff. For example, an increasing number of women have been awarded doctorates, have become academics, and finally females are increasingly moving into senior academic positions (Baker, 2009). Today, women at universities in New Zealand, Australia and Canada now occupy up to $20 \%$ of senior academic positions, as compared to less than $5 \%$ in the 1960s (Baker, 2009).

However, while the gap may be improving, inequality remains evident with higher attrition rates observed for female $\mathrm{PhD}$ candidates and junior academic staff, lower probability that women will gain a doctorate or acquire full time permanent positions, lower publication rates and lower salaries for female academics (Baker 
2009). The recent emphasis of universities to hire highly achieving and research productive academics and expect them to participate in international conferences, and publish in prestigious journals, may once again serve to further augment the gender gap (Baker, 2009).

In Australia, the proportion of males in senior ranks continues to be larger than of females, for both senior management positions and senior academic roles. For example, according to University Staff Profiles, in 2008 females made up 29\% of the Associate Professors, 21\% of the Professors , 32\% of the Deputy Vice Chancellors and $21 \%$ of Chancellors (Australian Vice-Chancellors Committee, 2008) yet females dominate junior academic ranks.

In Australia, the achievement of greater gender equity within Australian universities remains a significant and continuing issue as 'progress has been made but it is slow and not evenly distributed' (Universities Australia 2010, p. 2). While Australian universities have been at the 'forefront of encouraging changes in the gender balance' in their employment practices (Chesterman \& Ross-Smith, 2006, p. 541) and general equal employment opportunity legislation promotes gender equity in the workplace (Strachan, Burgess \& Sullivan 2004), gender inequity continues to exist in the Australian higher education sector [citation names deleted to maintain the integrity of the review process, year](Hartley \& Dobele, 2009).

While previous research acknowledges a gender imbalance, it is suggested that the inability to redress this disparity stems from an unwillingness to 'expose many of the most commonly accepted assertions to rigorous scrutiny' and that this unwillingness 'has prevented us from properly understanding the remarkable persistence of unequal outcomes for men and women in terms of pay and status' (Probert, 2005, p. 50). Thus, for universities to redress the continued imbalance between males and females further research (in addition to management action) is required.

Of the traditional three domains of academic staff, a secondary emphasis upon service (including administration, industry and community engagement) continues, with universities still placing greater importance on teaching and research as core university functions (Houston et al., 2006). These twin goals can be either synergistic and complementary or antagonistic and competing (Jenkins, 2004). Thus, if a university is to achieve the reform goals, (teaching and research excellence, with equity outcomes) to avoid potentially undesirable effects and counterproductive behaviours (Jenkins, 2004), the relationships between research, teaching, broader work expectations and rewards need to be defined and managed at the institutional, department and individual levels (Jenkins, 2004; Hartley \& Dobele, 2009).

By observing individual workloads, this paper reports the efforts of two metropolitan Australian universities to achieve equity outcomes using observable workload data. The reliance on actual workloads makes this research distinctly different from studies that have used aggregate workload data (e.g. Lafferty \& Fleming, 2000) or self-reported survey and focus group data (e.g. Probert, 2005). The null hypothesis we adopt is that the workloads of both male and female academics are equal.

\section{Research Methodology}

Similar to the approach of [name deleted to maintain the integrity of the review process, year] this research employed a case study method to observe academic 
workloads on key observable variables. The case study method was deemed appropriate for the research question because it describes the context of events (Yin, 2003) and is grounded in the social setting being studied (Jennings, 2001). The case study method has been used in previous research into gender equity (e.g., Toren \& Moore, 1998; Probert, 2005).

In this study multiple sources of evidence were used (Yin, 2003) to compile workload data for full-time academic staff. Sources include academic and university web pages, subject/course outlines, faculty enrolment records and faculty research office records. While previous research has considered Australia's Group of Eight Universities (see http://www.go8.edu.au/) (e.g., Asmar, 1999; White, 2004; Probert, 2005) or smaller, regional based universities [citation names deleted to maintain the integrity of the review process, year] little research has considered the observed workloads of mid-tier Australian universities. This research selected two mid-tier Universities; both based in capital cities, of two different states of Australia. The identities of the universities and the departments are withheld to ensure anonymity and are hereafter referred to as University 1 and University 2.

Data was sourced for both universities for the year 2007. University 1 data was sourced from a school comprising a mix of disciplines under one head of school, within a business college. University 2 data was sourced from a department under one discipline, within a business school. University 1 is a member of the Australian Technology Network and University 2 is a member of the Innovative Research Universities.

In this research the specific variables considered are the readily observable outputs from teaching duties and research. The measurement of teaching is considered on the basis of the number of subjects coordinated by a faculty member and the number of students enrolled. Research outputs are assessed based on the number of publications reported, and publications are counted in terms of DEEWR points (a system of measuring research outputs put in place by the Department of Education, Employment and Workplace Relations based on the number and type of research publications authored by academic and research active staff which were used to allocate Government funding to Universities). The DEEWR system came originally from a measurement system developed by the Department of Education Science and Training (DEST), whereby a value of one point is attached to most recognised outputs, including book chapters, conference papers and journal articles. Soleauthored publications receive the total value of one whereas shared authorship is divided by the number of co-authors.

We also considered research funding, measured in Australian dollars, and the number of successful research grants. Both internal (i.e. University, College or School) and external (e.g. industry or government) funding are considered simultaneously.

Analysis of the data comprised two distinct stages, firstly, an evaluation of the descriptive statistics, such as frequencies, percentages and summarised means, allowed the researcher to become familiar with the data (Tull \& Hawkins, 1980; Sekaran, 2000) prior to conducting multivariate analysis (Malhotra, 2004; Hair, Anderson, Tatham \& Black, 2005). Secondly, these descriptive statistics are the first warning sign of unexpected or out-of-the-ordinary results which may highlight incorrect data coding or entry. Stage two comprised the use of t-test and ANOVA techniques which both offer the ability to test group differences allowing academic workloads to be compared and contrasted by gender (Cardinal \& Aitken, 2006). 


\section{Results}

University 2 had more female staff than the Australian average while University 1 was male dominated. University 1 exceeded the Australian average for the proportion of academics at the Associate Professor and Professor ranks. At both universities the majority of staff had doctoral qualifications. University 1 academics were less research active (publishing papers and/or winning competitive grants) when compared with University 2 (Table 1 ).

A chi-square test of relatedness $\left(\chi^{2}=11.8, \mathrm{df}=4, \mathrm{p}<0.02\right)$ showed there were more women employed in junior academic ranks than men in both the universities in this study (Table 2). 
Table 1. Profile of academic employees

\begin{tabular}{|c|c|c|c|c|c|c|}
\hline \multirow[t]{2}{*}{ Variable } & \multirow[t]{2}{*}{ Items } & \multicolumn{2}{|c|}{$\begin{array}{c}\text { University } 1 \\
\mathbf{n}=39\end{array}$} & \multicolumn{2}{|c|}{$\begin{array}{c}\text { University } 2 \\
\mathbf{n}=27\end{array}$} & \multirow{2}{*}{$\begin{array}{c}\begin{array}{c}\text { Universities } \\
\text { Australia } \\
\text { average }^{1}\end{array} \\
\%\end{array}$} \\
\hline & & Freq. & $\%$ & Freq. & $\%$ & \\
\hline \multirow[t]{2}{*}{ Gender } & Male & 28 & 72 & 14 & 52 & 59 \\
\hline & Female & 11 & 28 & 13 & 48 & 41 \\
\hline \multirow{2}{*}{$\begin{array}{l}\text { Higher } \\
\text { degree } \\
\text { status }\end{array}$} & $\begin{array}{c}\text { Does not have a } \\
\text { PhD }\end{array}$ & 13 & 23 & 5 & 18 & \\
\hline & Has a PhD & 26 & 67 & 22 & 82 & \\
\hline \multirow{2}{*}{$\begin{array}{l}\text { Research } \\
\text { Active }\end{array}$} & Yes & 21 & 54 & 23 & 85 & \\
\hline & No & 18 & 46 & 4 & 15 & \\
\hline \multirow[t]{6}{*}{ Occupation } & Associate lecturer & 3 & 8 & 2 & 7 & 18 \\
\hline & Lecturer & 10 & 26 & 12 & 45 & 33 \\
\hline & Senior lecturer & 12 & 31 & 7 & 26 & 24 \\
\hline & Associate & & & 4 & 15 & $25 *$ \\
\hline & professor & 8 & 20 & & & \\
\hline & Professor & 6 & 15 & 2 & 7 & \\
\hline
\end{tabular}

* DEEWR statistics for Associate Professor and Professor ranks are combined

Table 2. Academic rank by gender

\begin{tabular}{|c|c|c|c|c|c|c|c|}
\hline \multirow[t]{2}{*}{ Variable } & \multirow[t]{2}{*}{ Items } & \multicolumn{2}{|c|}{$\begin{array}{c}\text { University } 1 \\
n=39\end{array}$} & \multicolumn{2}{|c|}{$\begin{array}{c}\text { University } 2 \\
n=27\end{array}$} & \multicolumn{2}{|c|}{$\begin{array}{c}\text { Universities } \\
\text { Australia } \\
\text { average }^{1}\end{array}$} \\
\hline & & $\begin{array}{c}\text { Male } \\
\%\end{array}$ & $\begin{array}{c}\text { Female } \\
\%\end{array}$ & $\begin{array}{c}\text { Male } \\
\%\end{array}$ & $\begin{array}{c}\text { Female } \\
\%\end{array}$ & $\begin{array}{c}\text { Male } \\
\%\end{array}$ & $\begin{array}{c}\text { Female } \\
\%\end{array}$ \\
\hline Occupation & $\begin{array}{c}\text { Associate } \\
\text { lecturer } \\
\text { Lecturer } \\
\text { Senior lecturer } \\
\text { Associate } \\
\text { professor } \\
\text { Professor }\end{array}$ & $\begin{array}{c}4 \\
18 \\
39 \\
\\
18 \\
21\end{array}$ & $\begin{array}{c}18 \\
46 \\
9 \\
\\
27 \\
0\end{array}$ & $\begin{array}{l}0 \\
36 \\
43 \\
14 \\
7\end{array}$ & $\begin{array}{c}15 \\
54 \\
8 \\
15 \\
\\
8\end{array}$ & $\begin{array}{l}15 \\
28 \\
25 \\
32\end{array}$ & $\begin{array}{l}39 \\
22\end{array}$ \\
\hline
\end{tabular}

1. Universities Australia 2007 averages obtained online at http://www.deewr.gov.au/HigherEducation/Publications/HEStatistics/Publications/Pa ges/Staff.aspx. Web site last accessed $19^{\text {th }}$ August 2011

To test the hypotheses t-tests were used (Hair et al. 2005). The hypotheses were twofold focussing on the most important functions, namely teaching and research. Both null hypotheses suggest that output is equal for male and female staff.

Difference was observed on one workload measure. Specifically, men ( $\mathrm{M}=2.2$ DEEWR points) had more papers published than women (M=1.4 DEEWR points) ( $\mathrm{F}$ $(52)=0.1, p=0.04)$ in the twelve months observed in this study. T-tests revealed no significant differences by gender for remaining four of the five workload measures observed in this study (Table 3).

Academic workloads, measured by research output (number of grants and dollar amounts of grants) and teaching (number of courses coordinated and number of students taught) do not differ between male and female academics. This was a surprising result as the number of men in senior academic ranks is higher than 
women, suggesting that while there is equity in workloads (on four out of five workload measures) there is inequity in terms of academic rank.

To provide insights by examining workload by academic rank we used a oneway analysis of variance (Hair et al. 2005). We first examined academic rank workload for each university (Table 3). We then examined academic rank workload for each gender (Table 4).

Table 3. Workload by academic rank - university

\begin{tabular}{|c|c|c|c|c|c|}
\hline \multirow[t]{2}{*}{ University 1} & \multicolumn{2}{|c|}{ Teaching } & \multicolumn{3}{|c|}{ Research } \\
\hline & $\begin{array}{l}\text { No. courses } \\
\text { coordinated }\end{array}$ & $\begin{array}{c}\text { Number of } \\
\text { students }\end{array}$ & $\begin{array}{c}\text { DEEWR } \\
\text { points* }\end{array}$ & $\begin{array}{c}\text { Number of } \\
\text { research } \\
\text { grants* }\end{array}$ & $\begin{array}{c}\text { Amount } \\
\text { of } \\
\text { research } \\
\text { grants* }\end{array}$ \\
\hline Associate lecturer & 3.5 & 463 & 0.5 & 0.0 & 0 \\
\hline Lecturer & 2.8 & 204 & 0.9 & 0.1 & $\$ 583$ \\
\hline Senior lecturer & 3.3 & 317 & 2.5 & 0.3 & $\$ 4,928$ \\
\hline Associate professor & 3.5 & 390 & 2.7 & 0.3 & $\$ 3,125$ \\
\hline Professor & 1.5 & 30 & 4.3 & 2.0 & $\$ 64,684$ \\
\hline \multirow[t]{2}{*}{ University 2} & \multicolumn{2}{|c|}{ Teaching } & \multicolumn{3}{|c|}{ Research } \\
\hline & $\begin{array}{l}\text { No. courses } \\
\text { coordinated }\end{array}$ & $\begin{array}{c}\text { Number of } \\
\text { students }\end{array}$ & $\begin{array}{c}\text { DEEWR } \\
\text { points* }\end{array}$ & $\begin{array}{c}\text { Number of } \\
\text { research } \\
\text { grants* }\end{array}$ & $\begin{array}{c}\text { Amount } \\
\text { of } \\
\text { research } \\
\text { grants* }\end{array}$ \\
\hline Associate lecturer & - & - & - & - & - \\
\hline Lecturer & 3.3 & 491 & 0.3 & 0.3 & $\$ 5,000$ \\
\hline Senior lecturer & 2.1 & 270 & 1.2 & 0.7 & $\$ 16,148$ \\
\hline Associate professor & 2.2 & 275 & 0.9 & 1.3 & $\$ 22,906$ \\
\hline Professor & 1.8 & 108 & 3.0 & 1.8 & $\$ 74,976$ \\
\hline
\end{tabular}

* Significant at the $\mathrm{p}=0.05$ level

Table 4. Workload by academic rank - Gender

\begin{tabular}{|c|c|c|c|c|c|}
\hline \multirow[t]{2}{*}{ Male } & \multicolumn{2}{|c|}{ Teaching } & \multicolumn{3}{|c|}{ Research } \\
\hline & $\begin{array}{l}\text { No. courses } \\
\text { coordinated }\end{array}$ & $\begin{array}{c}\text { Number of } \\
\text { students }\end{array}$ & $\begin{array}{c}\text { DEEWR } \\
\text { points* }\end{array}$ & $\begin{array}{c}\text { Number of } \\
\text { research } \\
\text { grants* }\end{array}$ & $\begin{array}{c}\text { Amount of } \\
\text { research } \\
\text { grants* }\end{array}$ \\
\hline Associate lecturer & - & - & - & - & - \\
\hline Lecturer & 2.6 & 240 & 1.2 & 0.2 & $\$ 1,400$ \\
\hline Senior lecturer & 3.2 & 229 & 2.5 & 0.2 & $\$ 2,833$ \\
\hline Associate professor & 4.5 & 412 & 1.9 & 0 & $\$ 0$ \\
\hline Professor & 1.0 & 15 & 5.6 & 1 & $\$ 31,185$ \\
\hline \multirow[t]{2}{*}{ Female } & \multicolumn{2}{|c|}{ Teaching } & \multicolumn{3}{|c|}{ Research } \\
\hline & $\begin{array}{l}\text { No. courses } \\
\text { coordinated }\end{array}$ & $\begin{array}{l}\text { Number of } \\
\text { students* }\end{array}$ & $\begin{array}{c}\text { DEEWR } \\
\text { points* }\end{array}$ & $\begin{array}{c}\text { Number of } \\
\text { research } \\
\text { grants* }\end{array}$ & $\begin{array}{c}\text { Amount of } \\
\text { research } \\
\text { grants* }\end{array}$ \\
\hline Associate lecturer & 3.5 & 463 & 0.5 & 0.0 & $\$ 0$ \\
\hline Lecturer & 3.0 & 179 & 0.7 & 0.0 & $\$ 0$ \\
\hline Senior lecturer & 4.0 & 848 & 2.3 & 1.0 & $\$ 17,500$ \\
\hline Associate professor & 2.5 & 370 & 3.5 & 0.5 & $\$ 6,250$ \\
\hline Professor & 2.0 & 45 & 3.0 & 3.0 & $\$ 98,150$ \\
\hline
\end{tabular}

* Significant at the $\mathrm{p}=0.05$ level

ANOVA testing indicated there was no significant difference between academic rank and the number of students and courses taught, suggesting equality across academic ranks for teaching load. However, significant differences emerged for the 
research output measures observed in our study. University $1(\mathrm{~F}(26,3)=7.9$, $\mathrm{p}=0.001)$ and $2(\mathrm{~F}(26,4)=7.5, \mathrm{p}=0.001)$ academics in senior ranks publish more papers than their junior counterparts. According to Tukey post hoc testing, Professors (Level E) published more papers than all other academic ranks. On the other hand, at University 2 Associate Professors and Professor (Level D and E respectively) published more papers than academics at Level B, Lecturer level.

Finally, senior academics won more grant money than their junior counterparts at both universities $1(\mathrm{~F}(28,3)=3.5, \mathrm{p}=0.03)$ and $2(\mathrm{~F}(26,4)=14.2, \mathrm{p}<0.001)$. Professors won more research grant income than lecturers and senior lecturers at University 1 and won more research grant income than academics at all other ranks in University $2(\mathrm{~F}(26,4)=14.2, \mathrm{p}<0.001)$. See Table 4 .

Analysis was then undertaken to examine workload by gender and academic level. Anova testing indicated there was no significant difference between academic rank and the number of courses taught, suggesting equality across academic ranks for both men and women. A significant difference emerged for the number of students taught $(\mathrm{F}(25,4)=8.2, \mathrm{p}<0.001)$ with female Professors teaching fewer students than their junior female counterparts.

Significant differences emerged across all three research output measures observed in our study for both men and women. Male $(F(27,3)=11.8, p<0.001)$ and female $(\mathrm{F}(24,4)=16.8, \mathrm{p}<0.001)$ academics in senior ranks publish more papers than their junior counterparts. According to Tukey post hoc testing male Professors published more papers than all other men in academic ranks B to D. Senior male academics $(\mathrm{F}(27,3)=3.5, \mathrm{p}=0.03)$ and female $(24,4)=90.1, \mathrm{p}<0.001)$ won more research grants than junior academics. Tukey post hoc testing indicated that male Professors won more research grants than academics at all other levels. Finally, both male $(\mathrm{F}(27,3)=23.2, \mathrm{p}<0.001)$ and female $(\mathrm{F}(25,4)=588, \mathrm{p}<0.001)$ senior academics won more research grant income than their junior counterparts.

\section{Summary of results}

Analysis was undertaken to explore workloads using five measures to understand the teaching and research responsibilities and outputs for academics at each rank. We found clear differences in terms of research output in senior academic ranks in the two universities. Despite general equality in workload, where workload was observed using two teaching and three research output measures, inequality in academic rank was evident in both universities.

An examination of workloads by academic ranks for male and female groups was illuminating. In particular female Senior Lecturers were outperforming males: coordinating more courses, teaching more students, publishing more papers and winning more grants (with a much higher dollar value) in both the universities under study. Examination of the descriptive statistics also suggests that female Associate Professors and Professors outperformed their male counterparts in terms of research outputs (published papers, number and dollar value of grants) in both universities studied, indicating that women are working harder for their money at these levels. We will now discuss the results of our research in light of the literature.

\section{Discussion}

One possible explanation for the causes of the inequality between male and female academics is the pipeline argument, which suggests that such differences are 
the consequence of scarce numbers of skilled women in the pool, rather than being persistent gender discrimination (Monroe and Chiu, 2010). However, even though the percentage of female academics in this pool has been increasing since the 1980s, the percentage of female professors has not shown enhancements in the same fashion. Hence, solely considering the pipeline phenomenon cannot solve the gender equity issue that is persistent in female career development regarding professions dominated by men (Monroe and Chiu, 2010). Across different countries, a mixture of frameworks has been used trying to explain the gender gap between men and women in academia.

Probert (2005) divides the underrepresentation of women at senior levels into unequal treatment of men and women at work and differing gender choices (i.e. parenting or career roles). According to Baker (2010), the academic gender gap has in the past been explained by various factors such as differences in social capital, family circumstances, academic priorities (teaching versus research) and publication rates. Barrett and Barrett (2011) suggest that the underlying reasons for gender inequality in higher education are complicated and cannot clearly be defined. However, they state that inevitably, women will have slower career progressions than men - due to personal choices arising from the differing gender roles - which might result in career breaks or a switch to part-time work (Baker, 2009; Baker, 2010; Barrett and Barrett, 2011) concludes that even though a higher percentage of women are now receiving doctorates in the English-speaking countries, many give up any prospects of reaching the professor rank because they leak out of the pipeline at an early stage or, if continuing, they prioritize family or teaching over research. The division of gendered roles in many households remains even when both partners have demanding careers and women progressing successfully in their career often show negative developments in their family lives (i.e. divorce, fewer/no children). Hence, gender identities and the household division of labour influence career aspirations, working hours, productivity and consequently progression through the ranks. Family life and its duties limits time and energy left devoted to the women's professional career advancement and therefore modify ambitions, productivity and rank at retirement. Hence, the continuing gender gap in academia reflects a combination of different family circumstances and perceptions of family/work responsibilities. It also reflects institutional practices that favour those with high levels of ambition, who work long hours, publish widely and remain productive throughout their working lives (Baker, 2010).

For the Australian higher education sector, achieving equity outcomes in the is one of the four broad themes of the Bradley report (Bradley, 2008) and a primary focus for the Australian Vice-Chancellors' Committee (Australian Vice-Chancellors Committee, 2002, p. 1) and thus, must remain on agendas and within University development discussions.

Following the approach used in previous research two observable components of workload (research outputs and teaching responsibilities) are observed. The two universities selected for this study represent institutions where female academics were evenly represented in senior academic positions, when compared to the National Universities Australia (2007) average.

This research extends our understanding of academic workloads and gender inequality. According to t-testing there were no significant differences between workloads for males and females on four of the five workload measures when a comparison was made across all academic levels. This supports [name deleted to maintain the integrity of the review process, year] who found equality in workloads in 
two regional Australian university and Probert (2005) who also found equity in workloads. Together, these findings diverge from older studies where gender workload inequity was characteristic of universities with females under-represented in senior academic positions (e.g., Cole \& Cole, 1973; Barbezat, 1992).

The results of the current study indicate that while workload equity is occurring academic rank equity is not occurring. Close examination of workload output between genders offers interesting insights, with females in many instances outperforming their male counterparts on certain workload measures. Despite females outperforming males within their own academic rank, universities continue to fail to achieve gender equity in terms of promotion to senior academic ranks. Perhaps a more proactive policy is required at university and/or government level if the nation is serious about redressing imbalances.

\section{Implications for academic workload practice}

An examination of workload patterns between academic ranks yields interesting insights which may inform policy development. Academic progression requires an individual to surpass a certain productivity threshold (McDowell, Singell \& Ziliak, 2000) and this work may provide some new understandings for academics seeking to benchmark their performance and better understand the level of work required for promotion. According to the results of this study the higher the academic rank, the higher the required research outputs and the lower the teaching demands (both in terms of the number of courses coordinated and the number of students taught).

The results of our study suggest that junior academics in the two business faculties are carrying the teaching load (in terms of the number of courses coordinated and the number of students taught). This leaves them with less time to develop their research capabilities. Such a finding is important as promotional panels are known to undervalue teaching compared with research (Acker \& Feuerverger, 1996) and it is a well-documented perception that women are not selected or promoted as readily as men (Winchester, Lorenzo, Browning \& Chesterman, 2006).

\section{Implications for policy}

While gender inequality is often not mentioned, and we understand why since acknowledging gender discrimination and inequality may be a serious problem for universities as this leaves them liable to lawsuits (Monroe and Chiu, 2010), the problem is a serious one and needs to be tacked head on. For despite the development of policies to promote gender equity in Australian universities, efforts have not yet achieved gender equity for academics to the extent or at the rate expected.

And yet, programs have been trialed which should have redressed this gap. For example, universities in most European countries have established special programmes that sought to promote women in natural sciences and technology. However, they did not have the expected success, measured over a period of 10 years. Even if structures were created to promote the employment and career development of women, cultural variables were driving against those strategies (i.e. ideas of gender roles and characteristics; male dominated structures and contents at universities). Hence, other ways have to be found that considers and realises complete gender equality in higher education (Mischau, 2001), and, unfortunately we are still attempting to find them.

Thus, an analysis of individual workload patterns, such as this one, can assist in informing further policy development. For both universities, females had higher 
observed research grant income while handling equal, or higher, teaching loads (in terms of course numbers). There is an important lesson in this outcome. Overall, our study suggests an imbalance remains between genders as it appears that female academics may not be getting promoted on the basis of workload performance. If Universities Australia is determined to attain gender equity for academics, then policy changes may be required to redress the remaining imbalances.

Universities will need to adopt proactive policy to redress the imbalance between men and women in senior academic ranks. University policy could be directed towards providing grant schemes specifically targeting women in junior academic ranks (i.e. Levels $A$ to $C$ ) to widen the number and value of grant opportunities that are currently available to women. Teaching buy-out schemes offering females the opportunity to concentrate on research for one semester may also assist to increase research output, thus increasing chances of promotion.

Additional initiatives could be implemented to increase publications from women in junior ranks, such as publishing syndicates, writing retreats, and mentoring programs, all of which are capable of increasing paper submissions. For example, writing retreats have been shown to provide positive benefits to participants by presenting opportunities to learn more about the writing process (which can aid future writing endeavours) and because the retreat represents protected time in which participants must write in a sustained manner (Grant, 2008). Additional incentives may include a bonus or increased research support for publication submission and/or acceptance for junior female academic staff in universities that are serious about redressing continuing gender inequity.

\section{Future research}

This study considered whether there was any difference in individual workload patterns for male and female academics in two Australian mid-tier universities by focussing on two observable workload areas: teaching responsibilities and research output. The results cannot be generalised beyond this context, nor can an assessment of overall workloads be gained as service workload is not directly observable. Additional research, in world-class research universities, is required to extend our understanding of academic workloads. Further research opportunities include extending our understanding of academic workloads beyond Australian shores, particularly to North America, Europe and Asia.

This study utilises data for one calendar year. A longitudinal study, observing workload over a number of years, would provide more insight on the factors contributing to academic promotion.

This study considered workload by using five observable measures. Many Australian universities now operate with highly specific workload models to govern individual academic workload. For example, in one Australian university workload policy currently requires all academic staff in its business school to mark for 100 hours each semester. A 50\% reduction can be obtained by paying casual markers using the staff members own research account. Another university provides teaching buyout for each research higher degree student supervised. Future researchers could obtain data using the Universities workload model adopted in universities to extend understanding of academic workloads. A more comprehensive understanding of research output could be provided by assessing the totality of research factors, including the quality of journals that academics publish in, the number of citations per paper published (e.g. as measured in Google Scholar or Scopus), and the number of 
research students graduated. Although measures may not be as easily observed, research output can also include invitations to speak at conferences and events, editorial advisory board representation, conference and journal quality and conference track chairing.

Clear and transparent selection and promotion processes based on attainment of research and teaching performance thresholds are worthy of consideration. Without clear benchmarks recruitment and promotion processes remain highly subjective with varying degrees of understanding existing between all individuals involved. Future research should consider whether the availability of clear communication of average levels of performance at each academic level for teaching and research would assist to further improve quality from both a student perspective over time. Clear benchmarks would illustrate how academics performing at the highest levels on both teaching and research are promoted based on overall performance.

Examination of these factors would further strengthen our understanding of individual academic workloads and provide further insight into the factors that assist academics to be promoted. 
Acker, J. \& G. Feuerverger (1996). Doing good and feeling bad: the work of women university teachers. Cambridge Journal of Education, 26, (3), 401-422.

Asmar, C. (1999). Is there a gendered agenda in academia? The research experience of female and male $\mathrm{PhD}$ graduates in Australian universities. Higher Education, $38,(3), 255-273$.

Australian Vice-Chancellors Committee (2002). AVCC Policy Statement on Gender Equity in Australian Universities.

--- (2008). University Staff Profile (1996-2005).

Barbezat, D.A. (1992). The Market for New Ph.D. Economists. Journal of Economic Education, 23, (3), 262-276.

Bradley, D. (2008). Review of Australian Higher Education. Message from the Chair. Retrieved $20 \quad$ October, 2008, from http://www.dest.gov.au/sectors/higher_education/policy_issues_reviews/reviews /highered_review/.

Cardinal, R.N. \& M.R.F. Aitken (2006). ANOVA for the Behavioural Sciences Researcher. Mahwah, NJ, US, Lawrence Erlbaum Associates Publishers.

Chesterman, C.J. \& A.E. Ross-Smith (2006). Not tokens: reaching a critical mass of senior women managers. Employee Relations, 28, (6), 540-552.

Cole, J. \& S. Cole (1973). Social stratification in science. Chicago, The University of Chicago Press.

Cutler, T. (2008). Venturous Australia: building strength in innovation. Review of the National Innovation System, Cutler\&Company Pty Ltd.

DEST (2005). Research Quality Framework: assessing the quality and impact of research in Australia. Department of Education Science and Training (DEST). Canberra, Commonwealth of Australia. March.

Gerhard, J. \& P. Mayr (2002). Competing in the e-learning environment: strategies for universities. Proceedings of the $35^{\text {th }}$ Hawaii International Conference on System Science, Hawaii.

Gillard, J. (2010). Prime Minister's Address to the Universities Australia Annual Higher Education Conference. Proceedings of the Universities Australia Annual Higher Education Conference, Canberra.

Grant, B.M. (2008). Academic Writing Retreats: A facilitator's guide. Milperra NSW, HERDSA.

Hair, J.F., R.E. Anderson, R.L. Tatham \& W.C. Black (2005). Multivariate data analysis. Englewood Cliffs, NJ, Prentice Hall. 6.

Hartley, N. \& A. Dobele (2009). Feathers in the Nest: Establishing a Supportive Environment for Women Researchers. The Australian Educational Researcher (AER) Journal, 36, (1), 43-58.

Heaney, J.G. \& M.F. Heaney (2008). Services Branding Strategies: Using Corporate Branding to Market Educational Institutions. School of Business Conference papers, Fremantle, University of Notre Dame.

Heaney, J.G., P. Ryan \& M.F. Heaney (2010). Branding private higher education institutions in Australia to International students. Proceedings of the Academy of World Business, Marketing \& Management Development Conference: paper \# 7, Oulu, Finland.

Houston, D., L.H. Meyer \& S. Paewai (2006). Acdemic Staff Workloads and Job Satisfaction: Expectations and values in academe. Journal of Higher Education Policy and Management, 28, (1), 17-30.

Jenkins, A. (2004) A Guide to the research evidence on teaching-research relations. The Higher Education Academy. 
Jennings, G. (2001). Tourism Research. Milton, QLD, John Wiley \& Sons Australia Ltd.

Lafferty, G. \& J. Fleming (2000). The restructuring of academic work in Australia: power, management and gender. British Journal of Sociology of Education, 21, (2), 257-267.

Malhotra, N.K. (2004). Marketing Research- An Applied Orientation. Upper Saddle River, NJ., Pearson Education Inc. 4.

McDowell, J.M., L.D.J. Singell \& J. P. Ziliak (2000). Gender and Promotion in the Economics Profession. Industrial and Labor Relations Review.

National Universities Australia. (2007). Higher Education Statistics. Retrieved $19^{\text {th }}$ August, 2011, from 〈http://www.deewr.gov.au/HigherEducation/Publications/HEStatistics/Publicati ons/Pages/Staff.aspx $>$.

Probert, B. (2005). 'I just couldn't fit it in': Gender and unequal work outcomes in academic careers. Gender, Work and Organization, 12, (1), 50-72.

Sekaran, U. (2000). Research Methods for Business A Skill-Building Approach. USA, John Wiley \& Sons.

Strachan, G., J. Burgess \& A. Sullivan (2004). Affirmative action or managing diversity: what is the future of equal opportunity policies in organisations. Females in Management Review, 19, (4), 196-204.

Toren, N. \& D. Moore (1998). The academic 'hurdle race': A case study. Higher Education, 35, (3), 267-283.

Tull, D.S. \& D.I. Hawkins (1980). Marketing Research: Measurement and Method. Macmillan Publishing Co., New York. $2^{\text {nd }}$ Edition.

Universities Australia. (2010). Universities Australia's Strategy for Women: 2011-2014. Retrieved Feburary 19, 2011, from http://www.universitiesaustralia.edu.au/.

White, K. (2004). The leaking pipeline: Women postgraduate and early career researchers in Australia. Tertiary Education and Management, 10, (3), 227-241.

Winchester, H., S. Lorenzo, L. Browning \& C. Chesterman (2006). Academic women's promotions in Australian universities. Employee Relations, 28, (6), 505-522.

Yin, R.K. (2003). Case study research: Design and methods. Newbury Park, CA, Sage. $3^{\text {rd }}$ Edition.

Baker, M. (2009). 'Gender, Academia and the Managerial University.' New Zealand Sociology 24(1): 24-48.

Baker, M. (2010). 'Choices or Constraints? Family Responsibilities, Gender and Academic Career.' Journal of Comparative Family Studies 41(1): 1-18.

Barrett, L. and P. Barrett (2011). 'Women and academic workloads: career slow lane or Cul-de-Sac?' Higher Education 61(2): 141-155.

Cooper, M. A. (2011). 'Salary Inequity in Higher Ed: Pay Gap Persists for Women.' The Hispanic Outlook in Higher Education 21(7): 14-16.

Gardner, S. (2007). 'AAUP Reports on Gender Equity.' The Hispanic Outlook in Higher Education 17(11): 34-36.

Lanier, P. A., J. R. Tanner and B. N. Guidry (2009). 'A Comparison of Gender and Gender-Related Issues in the Business Disciplines.' Public Personnel Management 38(3): 51-70.

Mischau, A. (2001). 'Women in higher education in Europe - a statistical overview.' International Journal of Sociology and Social Policy 21(1/2): 20-31.

Monroe, K. R. and W. F. Chiu (2010). 'Gender Equality in the Academy: The Pipeline Problem.' PS: Political Science \& Politics 43(2): 303-308. 
Probert, B. (2005). 'I just couldn't fit it in': Gender and unequal work outcomes in academic careers.' Gender, Work and Organization 12(1): 50-72. 